\title{
Standard Review of Freedom of Expression and Censorship in Nepal
}

\author{
Narayan Datta Kandel
}

\begin{abstract}
It was expected that the recent political and constitutional transformations will lead to the institutionalisation of liberal democracy in Nepal. This in turn was to lead to the freedom of expression, an essential tool for the effective participation in any democratic process. This paper will seek to offer i) historical analysis of the existence or otherwise of the freedom of expression in the constitutional and the legislative framework in Nepal ii) an analysis of the loopholes and anomalies in the new Constitutional and legislative framework which have led to the increasing restriction of the freedom of expression through censorship in the country, iii) will try to show that democracy and peace in Nepal can't be secured, at least in the long run, without the constitutional and legislative guarantee of the freedom of expression.
\end{abstract}

Index Terms-Freedom of expression, media, censorship, reasonable restriction, freedom of information, limitation on freedoms, democracy, effective participation, justification of censorship.

\section{INTRODUCTION}

Nepal's constitution protects freedom of expression as a fundamental right, guaranteed against unreasonable suppression or regulation. Although this freedom of expression is recognized as a key principle of the country's constitution, there is an ongoing debate regarding the level of protection offered. Some experts argue that freedom of expression should be given a special degree of protection in the constitution to ensure full democratic exercise [1]. Exercising this right carries special duties and responsibilities; therefore, reasonable restrictions may be necessary. Nepal's constitution and legislation contain protective standards for restricting freedom of expression. Compelling justification is required to create restrictions, as described in Article 19, paragraph 3 of the 1966 International Covenant on Civil and Political Rights (ICCPR). Nepal's restrictions should therefore be rigorously tested and compared to ICCPR standards.

How do the different standards and mechanism which protect freedom of expression affect the quality of democracy in Nepal? To answer this question, the country's standers and instruments of restriction should be tested and scrutinised to determine whether it is appropriate and proportionate. This paper describes the mechanism used in Nepal to protect freedom of expression and the restrictions imposed via the country's constitution and legislation. Constitutional provisions, legislation, rules and regulations,

Manuscript received September 7, 2016; revised March 1, 2017.

Narayan Datta Kandel is with Queen's University Belfast, UK (e-mail: kandeln2015@gmail.com). government policies and directives that may affect freedom of expression are considered in this paper.

\section{INTERNATIONAL FRAMEWORK}

International instruments provide guidelines for legislating freedom of expression and limiting freedoms and tools to incorporate these guidelines into national law and policy. International law obligates each state to guarantee the rights of its citizens.

The 1948 Universal Declaration of Human Rights was the first key international instrument to recognize freedom of expression as a fundamental human right. The 1966 International Covenant on Civil and Political Rights protects this freedom in Article 19, which defines freedom of expression as the freedom to "seek, receive and impart information and ideas of all kinds." This guarantee explicitly acknowledges the transboundary scope of these rights [2]. The exercise of freedom of expression should not be limited by media type, as the document specifically accommodates future technological advances [3].

Article 19 of the ICCPR states that freedom of opinion is an absolute right and freedom of expression encompasses 1) seeking information and ideas through any media, regardless of frontiers; 2) receiving information and ideas through any media, regardless of frontiers and 3) imparting information and ideas through any media, regardless of frontiers. According to the European Court of Human Rights, information and ideas of all kinds refers not only the information and ideas that are favourably received or regarded as inoffensive or indifferent but also those that offend, shock or disturb the state or any sector of the population (subject to certain restrictions) [4]. Paragraph 3, Article 19 of the ICCPR states that freedom of expression may be limited to 1 ) respect the rights or reputations of others, 2) protect national security, 3) protect public order, 4) protect public health or 5) protect public morals. In addition, all restrictions must pass a three-part test; a restriction must 1) be provided by law, 2) be imposed for legitimate grounds and 3) conform to a strict test of necessity and proportionality. The European Court of Human Rights ruled that restrictions must be justified by the proven existence of a pressing social need and that the expression "provided by law" implies two requirements: Firstly, the law must be adequately accessible. Secondly, a norm cannot be regarded as law unless it is formulated with sufficient precision to enable a citizen to regulate his conduct [5].

The international and regional human rights systems require strong justification for any restrictions on freedom of expression. The European, African and American human rights mechanisms have influenced the evolution of human 
rights and related legal standards worldwide, including Nepal.

\section{DEVELOPMENT OF FREEDOM OF EXPRESSION IN NEPAL}

In Nepal, human rights, including freedom of expression, were not a matter of public policy until 1990. Some fundamental rights were provided in constitutional documents as early as 1948, but these provisions were never protected in practice. From 1846 to 1951 Nepal was ruled by hereditary Rana prime ministers (Shree Tin Maharaj) who dominated the monarchy. In 1950, political parties formed, and started an armed movement against the Rana administration to established a democracy. The sovereignty of the king was restored in 1951 and a new government was formed in association with established political parties.

Two constitutional documents, the Interim Government Act of 1951 and the Constitution of Nepal of 1959, were enacted by the monarchy but did not establish any real human rights. The latter was supposed to establish a multiparty democracy, but was instead used by the king to create an absolute monarchy. In 1962, a new constitution in which fundamental freedoms were not fully guaranteed was enacted based on the absolute monarchy.

In 1990 Nepal underwent a huge political and constitutional transformation, from a party-less political system driven by an absolute monarch to a parliamentary democracy and constitutional monarchy. Human rights were recognised as key principle of the new constitution. The 1990 constitutional revolution recognized human rights as the key benchmark by means of which public policy should be examined.

On 14 May 1991 the government of Nepal ratified the International Covenant on Civil and Political Rights (ICCPR) 1966. This brought the activities of Nepal's public bodies under significant national and international scrutiny and obligated the country to enact domestic legislation in harmony with ICCPR guidelines and institute conformity within its bodies.

The new constitution created a mechanism to realise fundamental rights through the judiciary. Extraordinary jurisdiction was granted to the judiciary to evaluate and correct the activities of the other branches of the government, including the legislative branch, through judicial review [6]. Every Nepalese citizen was offered the power to control public activities through extraordinary jurisdiction; any citizen could file a petition to have any law or part of a law declared void, provided the law violated the constitution or imposed unreasonable restrictions on fundamental rights (Art 88 The Constitution of the Kingdom of Nepal 1990). This has proven to be an effective tool to develop laws to protect human rights in line with constitutional standards. On many occasions, activities of public bodies were declared unconstitutional because they imposed unreasonable restrictions on the constitutional rights of ordinary people [7]. In fact, judicial review has significantly contributed to the development, promotion and protection of fundamental rights in Nepal.

In terms of addressing public interest through litigation, in principle, Nepalese judicial review more effectively safeguards rights from restrictive legislative activity than judicial review in the United Kingdom (UK). Due to the UK principle of parliamentary supremacy, acts of parliament are not subject to judicial review. Legislation passed by the UK's parliament cannot be questioned or overturned by the judiciary, even if it limits freedom of speech [8]. In Nepal, extraordinary jurisdiction allows the courts to review acts of parliament and declare laws or parts of laws void if they impose unreasonable restrictions on constitutional freedoms. However, this powerful tool is ineffective during armed conflicts. For example, during the royal takeover of 2005 all remedial mechanisms, including judicial review, failed or were ineffective.

During the 2005 royal takeover, constitutional and legislative guarantees of freedom of expression were supressed and denied [9]. The government imposed unreasonable restrictions on freedom of expression and complaints brought to the Supreme Court for judicial review were not heard until the liberal political system was restored.

(Advocate Tulsi Ram Niraula v Government of Nepal PN 2829 (SC Nepal 2007) and other important cases) The government issued an ordinance amending communication and information-related legislation, which significantly limited the right to freedoms of expression and mass media. Radio Sagarmatha brought this case to the Supreme Court, seeking judicial review. The case was heard after the restoration of the political system and parliamentary action to replace the ordinance.

In 2006 conflicting parties reach a comprehensive peace agreement to end decade long armed conflict. The main instrument of the agreement was the formation of an elected constituent assembly in 2008. Following the decade-long armed conflict and transitional process, a new constitution was enacted by the constituent assembly. The new constitution embraces the principles of republicanism, federalism, secularism, and inclusiveness.

Huma right is also a key principle of this new constitution. But a brief discussion is essential to determine how this new constitution protects rights to freedom of expression.

\section{CONSTITUTIONAL Foundations OF FREEDOM OF EXPRESSION}

"We the sovereign people of Nepal...do hereby pass and promulgate this constitution through the Constituent Assembly" mentioned in the preamble of the constitution. As the power to promulgate this constitution is vested in the Nepalese people, the people agree to be governed by its fundamental principles which concern human rights, including full freedom of the press, as provided for in the preamble.

Part three of the constitution includes a long list of fundamental rights. Every citizen of Nepal has a right to freedom of opinion and freedom of expression (Article 17(2) a of the Constitution of Nepal 2015), the right to communication freedom from prior censorship (Article 19 (1) on the information and ideas to be published, broadcast, disseminated. It provides some level of freedom from interruption, except in accordance with the laws of Nepal (Article 19 (3). 
Article 19 also provides protection to the means of communication, equipment from being seized and registration being cancelled. The constitution also protects the right to information, which allows citizens to demand and receive information of personal interest or information of public interest (Article 27).

These rights somewhat reflect a continuation or expansion of Nepal's 1990 constitution. However, in the revised constitution, the previous provisions are elaborated in a bid to include additional aspects of rights, although the effectiveness of this effort still needs to be examined. Restrictive provisions were also expanded beyond those listed in the 1990 constitution.

However, these guarantees, as set forth in the constitution, were not formulated in line with international standards and therefore may not encourage the exercise of full democratic freedoms.

In ICCPR freedom of opinion is absolute without interference whereas freedom of expression can be subjected to reasonable restriction. But Article 17, Section 2 (a) of the Nepalese Constitution provides the same level of protection to both the freedom of opinion and freedom of expression.

In contrast to common international practice, in Nepal the freedoms of opinion and expression only apply to the individual citizen. This is similar to India's constitutional practices, which are somewhat discriminatory regarding freedom of expression. India is more sensitive than Nepal when it comes to foreign involvement in the press or any publication-related businesses. For example, the Indian Supreme Court ruled that a non-citizen who runs a newspaper in India is not entitled to the same fundamental rights of freedom of expression or freedom of the press afforded to an Indian citizen [10]. Some argue, however that, similarly Nepal is incapable of treating citizens and noncitizens equally under the law. This means individuals could be denied freedom of expression based on their country of origin or nationality. Others argue that Nepal's restrictions serve the country's national interests and are allowed by international law; however, these practices do not conform to the ideals of a democratic state. The fundamental nature of freedom of expression calls for protection that transcends borders, which is not reflected in Nepal's constitutional guarantees.

It is unclear what kinds of activities are protected under the current constitutional provisions regarding freedom of expression. The International Covenant on Civil and Political Rights and other international instruments clearly define freedom of expression as the freedom to seek, receive, and impart ideas of all kinds. In contrast, Nepal's constitution simply states that, "Every citizen shall have (a) freedom of opinion and expression." It offers no further explanation beyond the related restrictive provisions. In addition, the right to information includes the right to seek and receive significant information of personal or public interest, but not the right to seek and receive information and ideas of "all kinds."

Freedom of expression needs to be protected by Nepal's constitution, for the activities explicitly specified within the text. This protection must include the right to seek, receive, and impart ideas and information; without these provisions freedom of expression becomes meaningless. In the absence of any one of these features, the objective of the right to freedom of expression cannot be achieved.

Without clear constitutional guidance, Nepal's judiciary will not be able to establish the necessary guidelines to protect these freedoms. In 1987, books written by Devendra Raj Pandey on Nepal's economic issues were seized and held by the Bagmati administration. Nepal's censorship law requires an author to submit two copies of a requested book for review, but Mr. Pandey was instructed to submit all copies of his work-and he complied. The Bagmati administration held his books for almost two years, preventing their distribution. After two years, Nepal's courts issued a directive to release the books on the ground that a procedural gap had occurred [11]. However, the courts failed to recognise the author's right to circulate his work in their directive.

Article 19 of Nepal's constitution protects the right to communication. This right is specific to the use of mass media. In India, there are no separate provisions for mass media-mass media enjoys the same freedom of expression as an individual. This provision provides protection against prior censorship, arbitrary cancellation of registration, arbitrary closure or seizure of equipment, and arbitrary interruption of means of communication. It also provides some level of protection for imparting certain ideas and information. It does not recognise the specific scope of 'information and ideas of all kinds to be protected, nor does it includes all kind of media.

International human rights mechanisms provide the same protections to all types of media with regards to freedom of opinion and freedom of expression per article 19 of the ICCPR, which was drafted with the foresight to accommodate future technological advances [12]. However, Nepal's government seems less tolerant of electronic and digital media than other more traditional media. For example, Dinesh Acharya, the editor of Share Bazaar Weekly, was arrested for posting a published news item on his Facebook page, while the same news item was published in Nepal's newspapers without incident (IFEX report from $1^{\text {st }}$ October 2013). It seems that Nepal's government is not ready to acknowledge the value of internet-based media, perhaps because of its effectiveness and widespread reach. Otherwise, why would uploading published materials to the internet or social media be considered a crime? Overall, the level of protection available to users of traditional media is somewhat higher than that afforded to users of digital media.

\section{CONSTITUtional PROVISION OF RESTRICTIONS}

Nepal's constitution subjected freedom of expression and freedom of opinion to certain limitations and restrictions. The differences between Nepal's restrictions and international law have a significant impact on fundamental rights. Therefore, it is essential to put all restrictive provisions through the three-part test to determine their proportionality in achieving legitimate interest.

The constitution proposes twenty different grounds to justify limitations on freedom of expression. According to Article 17, section 2a, (1) the right to freedom of opinion and expression shall not "prevent the making of an Act to 
impose reasonable restrictions on any act which may undermine the sovereignty, territorial integrity, nationality and independence of Nepal or the harmonious relations between the Federal Units or the people of various castes, tribes, religions or communities or incite caste based discrimination or untouchability or on any act of disrespect of labour, defamation, contempt of court, incitement to an offence or on any act which may be contrary to public decency or morality."

Most of the exceptions specified in these restrictive clauses are also found in international law. A few, such as "harmonious relations between federal units" and "reference to nationality" are very low standards for imposing legitimate restrictions.

Protection of the national sovereignty and territorial integrity of the country provides valid grounds for the restriction on freedom expression. Under the international law the national security is valid ground for the restriction on the freedom of expression whereas under the Nepalese Constitution protection of the national sovereignty and territorial integrity serves as the valid ground for similar restriction. However, the use of term nationality in this section does not seem to serve any usefulness in this context

The national sovereignty and territorial integrity of Nepal, provides valid grounds for restrictions in the name of national security; however, the term "nationality," as used in this section, hardly justifies any legitimate threats or interests.

The reference to harmonious relations among different religions, castes, tribes, and communities is more problematic. Of course, promoting harmonious relations among populations is a legitimate goal, and it can be argued that some forms of freedom of expression could potentially jeopardise positive discussions or support discrimination. However, it can also be argued that progressive discussion or thought that empowers underprivileged communities may positively impact harmonious relations. Only discriminatory activity and expressions, such as hate speech, should be restricted, as per article 20 of the ICCPR.

Federal units are merely political divisions or a means of decentralisation of governance of a country. Maintaining harmonious relations between federal units can be in the best interests of the nation; which can be achieved through government policies and programmes. Any limitation on the freedom of expression to protect harmonious relations between federal units would discourage people from criticising the government policy on decentralisation. Enabling a more constructive dialogue between the government and the ordinary people is one of the main functions of democracy. Risking this democratic objective may not be justified as proportionate to maintaining harmonious relations between federal units.

The 'disrespect' for labour is totally out of the scope of the legitimate interest to limit the freedom of expression. Promoting a respect for labour is, of course, a valid intention of a political society, but anything otherwise could not be reconciled with fundamental freedoms. A respect for labour can be achieved through policies or programmes that augment the lifestyles of hardworking people and by securing labour rights through strong legal mechanisms.
Article 48 (C) of the constitution deals with the duties of the citizen. One of the duties and responsibilities is to render compulsory service as and when the state so requires. This provision somehow reflects the coercive intention of the state to compel people to offer their labour to the government. This concept massively conflicts with the principle of civil liberties. In the case of the implementation of this provision, there could be a huge debate on the nature and scope of civil liberty. The intention of this restriction based on respect for labour could be construed as means to interrupt such debates.

The restrictive clause of the freedom of expression are looks like as an item of laws rather than legitimate interest. Such as defamation is a law to protect the reputation of others. Contempt of court and the incitement of crimes are laws that maintain the public order and respect for the rights of others.

Including these laws in restrictive provisions may automatically acquire the status of the constitution. Whereas laws imposing restrictions on the freedom of expression should be made subject to the constitutional test. Moreover, the phrase 'may undermine' does not reflect pressing needs that lower the standards of the legitimate interest.

The concept of the national interest has been protected by strong provisions in the current constitution (Article 5). The safeguarding of freedom, sovereignty, territorial integrity, nationality, independence and dignity of Nepal, rights of the Nepalese people, border security, economic wellbeing and prosperity shall be the basic elements of the national interests of Nepal.

Freedom, the dignity of Nepal, the rights of the Nepalese people, border security, economic wellbeing and prosperity are new concepts, and they were not included in the restrictive provision regarding the rights to free expression and opinion, the right to information and the right to communication. These concepts restrict the rights and freedoms provided elsewhere in the constitution. According to Section 2 of Article 5 of the constitution, any conduct and act contrary to the national interest shall be punishable by the federal law (Article 5 (2).

Serving the national interest is a welcome goal; however, the consequences of this provision can have a negative impact on the freedom of expression. Section 15 of the Press and Publication Act and Section 7 of the National Broadcasting Act prescribed the national grounds to impose prior restrictions on publication and broadcasting. The supreme court also held that the government may determine how the national interest can be served and validate these legal provisions [13]. With the new constitution's evolution, the constitution itself determines the elements of national interest that would bring further restrictions.

By virtue of the supreme court's acknowledgement and legislative provisions, the ten different elements of these constitutional provisions are automatically part of the restrictive provisions elsewhere in the constitution. Accordingly, Section 2 of Article 5 declares that all conduct and acts contrary to the national interest are punishable. The spirit of this provision and purposed punishment clearly erode the foundation of the freedom of expression that is recognised and established as a principle by the European 
Court of Human Rights in Handyside v United Kingdom [14].

Democratic activities such as criticising the government would be punishable under this provision. Anyone criticising the government's economic policy would be seen as contrary to economic wellbeing and subject to punishment.

In terms of the meaning and value of protected elements, they can be achieved through progressive governmental programmes and policies. Constructive dialogue among the people is essential to serve the national interest rather than imposing restrictions on fundamental rights.

\section{STATE OF EMERGENCY}

According to article 273 (10) of the Constitution of Nepal 2015 , in the event of state of emergency, fundamental freedoms can be suspended. Except for the rights provided in Article 19, Section 2, all the other rights related to the freedom of expression and opinion would be suspended with the declaration of a state of emergency. The exception covers freedom from being seized regarding means of communications, the press and equipment, as well as the mass media's freedom from closure and their registration being cancelled.

No petition may lie in any court for the enforcement of the fundamental right conferred by that Article; nor may a question be raised in any court regarding the suspension of the freedom (Article 273 (11).

Nepal experienced a very negative state of emergency during the Maoist insurgency in terms of freedom of experience. Freedom of expression was completely denied during that period. The mass media were arbitrarily closed, communication equipment was captured, and journalists were intimidated into self-censorship. Intimidation and interference in newspaper editorials were normal [15].

The emergency provision in this constitution proposed the unconditional suspension of fundamental rights. Article 4 of the ICCPR provides a derogation of rights during the state of emergency but set both procedural and substantial conditions for such derogations. Such conditions, inter alia, are derogations and may only be imposed where the emergency threatens the life of the nation. A derogation may only limit rights to the extent strictly required and may never lead to discrimination. The Nepalese constitution does not recognise this condition and proposes a derogation of rights without an assessment of situations.

\section{LEGISLATIVE PROVISIONS AND CENSORSHIP}

If one examines the imposition of restriction in practice, the Provision of International Human Rights instruments and constitutional provisions are overridden by ordinary and delegated legislation. Nepal has a written constitution, and constitutional supremacy is expected to be maintained.

Of course, there is the avenue of judicial review to maintain a uniform mechanism guided by the constitution and international standards; however, the judicial review mechanism is not effective. Legislations declared void on constitutional grounds are not practically eliminated. Rules and regulations to implement such voided legislation are not revised.

Regarding the reception or implementation of an international treaty in which Nepal is a state party, the latitude of international treaties and human rights instruments in the Nepalese legal system is unclear. The judiciary, which just uses them as reference, normally does not accept the principle of overriding constitutional provisions. The constitution is the fundamental law of Nepal, and any law inconsistent with this constitution shall, to the extent of such inconsistency, be void.

Section 9 (1) of the Treaty Act 1990 of Nepal accords international treaties to which Nepal is party the status of domestic law. This law also provides that, in the case of conflict between the provision of domestic law and the treaty, the treaty provisions prevail. The treaty act cannot override the constitution, as it is the law of the land. However, the constitution is also domestic law, do not the provisions of the treaty act as mention above contravene to the constitutional provision? Obviously, the situation is complicated, but the constitution should be made to possibly conform to international standards. However, any ordinary act of parliament shouldn't contravene the spirit of the constitution.

\section{MASS MEDIA AND CENSORSHIP}

The Press and Publication Act 1991 imposed restrictions out of the scope of the constitution. Section 15 of the act provides that the Government of Nepal may, in view of the national interest, by publishing a notification in the Nepal Gazette, prohibit the publication of any news, information or other reading material relating to any specific subject, event or area until the period specified in the notification or allowing the publication only upon the same being examined or verified by the authority specified in the notification.

This provision not only overrides the Nepalese constitution but also violates the substantial and procedural requirements set out by international law. The law allows the government to impose restrictions by publishing a notification, as the international law strictly requires that any restriction must be provided by law. The European Court of Human Rights sets out two requirements to satisfy those provided by law [16].

The grounds proposed here is the national interest, which is not a legitimate interest as set out in Article 19 Section 3 of the ICCPR. It may prohibit 'any' news and information. It recognises government interference in the freedom of expression as the authority requiring any materials to be examined or verified before publication. This provision was challenged as unconstitutional in 2005, but the supreme court remained silent on the requirements set out by international law and international bodies. The court held the constitution allows the legislature to make laws to impose reasonable restrictions on the freedom of expression, and parliament can determine the national interest so this law is not unconstitutional.

Similar provisions are made in the National Broadcasting Act of 1993. Section 7 of the act states that, taking into account national interest, the government of Nepal may, by 
a notification published in the Nepal Gazette, prevent any programme pertaining to any particular subject, event or area from being broadcast by a broadcasting institution, for a period not exceeding six months at a time. This rule is very similar to Section 15 of the Press and Publication Act; however, it adds 'the nation' to 'national interest' as a subject that can be used as grounds for restriction. The term 'nation' can't be legitimate interest unless its security and existence of nation is threatened. The constitutionality of this provision has been challenged, but the petition was rejected by the Supreme Court.

Section 8 of the National Broadcasting Act was declared void by the Supreme Court in 2005 . The court held that any interruption of the free flow of expression through electronic media, or the cancellation of the registration of such media, imposed an unreasonable restriction in an indirect way [17]. However, despite having been declared void, Section 8 is still in invoked in practice. Rule 18 of the 1995 National Broadcasting Regulation provides the government with the right to cancel a broadcasting license, a delegated provision of Section 8. This shows a gap in implementation of judicial review, as relevant laws and regulation have not been revised to comply with the court order.

The 2007 Right to Information Act deals with the right of citizens to request and receive information. The Right to Information Act provides guidelines on which bodies or institution have a responsibility to provide information, what kind of materials constitute information and who is entitled to receive the information.

The public bodies subject to the law are named in Section 2 (a), while Section 2 (b) defines 'information' as any written document, material or information related to the functions, proceedings or decisions of public importance made by a public body. These legal provisions seem to be appropriate as a formal and long procedure to obtain information.

Sub-section (c) of the act stipulates the meaning of 'public importance': a subject related directly or indirectly to the interest of citizens. However, this is rather vague; who is to decide whether a particular piece of information is of public importance or not?

An easy route for citizens to access information of public importance needs to be developed so they can be informed about issues affecting them more clearly and effectively.

\section{Status of Online Communication}

Nepal has enacted directives to regulate online media under the authority of the 2008 Good Governance (Management and Operation) Act. It is likely that these directives were placed under the Good Governance Act because media-related law is stricter about government control of the media. Section 21 of the act includes provisions allowing the government to block or disrupt the services of a website if the site publishes materials that are deemed illegal or immoral, do not have 'an authoritative source' or 'create misconceptions among the public', or if the site's owner fails to register or renew its registration [18].

This provision allowing the government to block a website contradicts the constitutional provision stating that no form of media shall be interrupted by the government. Section 11 stipulates a range of restrictions on freedom of expression, most of which can be found in the Constitution and other legislation already discussed. The current regulations on material that is 'restricted from being published or broadcast' includes materials 'that do not have official sources, create misunderstandings and have an adverse effect on international relationships'. Before enactment of these directives, the Nepalese legal framework had denied new media, such as online news sites or blog or social media, the same status or recognition as the traditional print media. In 2013 Journalist Dinesh Acharya, editor of Share Bazar Weekly, published a news story about the industrialist Nirvan Chaudari. A few days later, he posted the same news in the facebook. Nepalese Police arrested journalist Acharya following the complaint made by Mr Chaudari for posting the already published news in the facebook. What this case highlight is that, in principle, publishing news in newspaper and publishing news or sharing news online is not treated the same as printed media is treated.

Free expression in online media is not as well tolerated as in traditional print media, which is contrary to international practice as well as the Nepalese Constitution.

\section{CONCLUSION}

The conclusions to be drawn from the above discussion are i) the new constitution and legislative framework in Nepal fails to meet internationally recognised requirements regarding the freedom of expression to the extent that, it does not guarantee to every citizen "the right to seek, receive and impart the ideas of all kind", as the expression in the new constitution that 'every citizen should have freedom of opinion or expression, is very vague and open ended, and thus subject to conflicting interpretations; ii) the new constitutional and legislative framework doesn't seems to have learned the necessary lessons from the history of arbitrary suppression of the freedom of expression by those in power; iii) the new Nepali constitution seems to allow the restriction of the freedom of expression on 20 different grounds rather than five specific and restrictive grounds as allowed by the international standards; iv) the restrictions imposed do not comply with the internationally recognised three tests, such as the need to be sanctioned by law, imposed for the legitimate grounds and compliance with the test of necessity and proportionality; v) as the case of Acharya $\mathrm{v}$ Chaudary demonstrates that in Nepali legal system and practice, the new media, such as online news blogs/social media, etc., are not given the same respect and recognitions as afforded to the traditional print and electronic media; vi) the recommendation of this paper is that the new democracy in Nepal is very fragile and it's long term future can only be assured by the respect for the freedom of expression, both in law and practice, in accordance with the currently accepted international standards.

\section{REFERENCES}

[1] E. M. Barendt, Freedom of Speech, (Oxford University Press 2005), p. 6.

[2] United Nations, General Assembly, Report of the Special Rapporteur on the Promotion and Protection of the Right to Freedom of Opinion and Expression, A/HRC/29/32 paragraph 25 
[3] United Nations, General Assembly, Report of the Special Rapporteur on the Promotion and Protection of the Right to Freedom of Opinion and Expression, $\mathrm{A} / \mathrm{HRC} / 17 / 27$

[4] Handyside $v$ the United Kingdom, Application No. 5493/72 (7 December 1976 European Court of Human Rights) Paragraph 49

[5] The Sunday Times $v$ The United Kingdom App no 6538/74 (ECtHR, 26 April 1979) para 59

[6] B. Acharya, Comparative System of Judicial Review, (A.K. Books and Educational Enterprises Pvt Ltd 2012 Kathmandu)

[7] R. K. Timalsena, Some Landemark Decision of the Supreme Court of Nepal (Supreme Court of Nepal 2003)

[8] H. Fenwick, Civil Liberties and Human Right, $3^{\text {rd }}$ edition (Cavendish Publishing Limited London 2002) p. 3.

[9] Nepali Press During the State of Emergency, FNJ Nepal 2005.

[10] MSM Sharma v Krishna Sinha AIR 1959 SC 395

[11] Devendra Raj Pandey v Bagmati Administration NLR 2045/36 CN 36 (1989 SC Nepal)

[12] United Nations, General Assembly, Report of the Special Rapporteur on the Promotion and Protection of the Right to Freedom of Opinion and Expression, $\mathrm{A} / \mathrm{HRC} / 17 / 27$

[13] Narayan Kandel v Government of Nepal Ministry of Information and Communication and others SC Precedents on Information and Communication (FF Kathmandu 2006) 135.

[14] Handyside $v$ the United Kingdom, Application No. 5493/72 (7 December 1976 European Court of Human Rights) Paragraph 49

[15] United Nations, General Assembly, Report of the Special Rapporteur on the Promotion and Protection of the Right to Freedom of Opinion and Expression, A/HRC/29/32

[16] The Sunday Times $v$ The United Kingdom App no 6538/74 (ECtHR, 26 April 1979) Paragraph 49
[17] Narayan Kandel v Government of Nepal Ministry of Information and Communication and others SC Precedents on Information and Communication (FF Kathmandu 2006) 186.

[18] Online Media Directives (2015 Nepal) Section 21

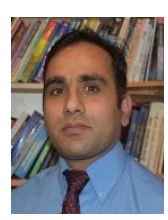

Narayan Datta Kandel is a $\mathrm{PhD}$ student in Queens University Belfast working on 'Freedom of Expression in Context of Nepal. The author has worked in Nepal as a journalist and a lawyer. My career as a journalist began at the national radio station, Radio Nepal, after which I worked as a reporter at the national daily newspaper, the Rajdhani Daily. During this period, I was a branch president of the Federation of Nepalese Journalists Dhaulagiri Branch.

He left full-time journalism to study law and after graduation began my court practice as a solicitor in the areas of human rights and press freedom. He brought two successful Supreme Court constitutional case seeking amendment of censorship provision of legislation. As a lawyer associated with a number of different organisations he has conducted many cases relating to press freedom and the rights of the individual in Nepal.

$\mathrm{He}$ have been arrested and detained twice in Nepal in relation to his activities regarding press freedom and human rights during autocratic Royal regime. Mr Kandel was a founding member and served on the executive committee of the Nepal Freedom Forum. The author completed LLM in International Human Rights Law at the University of Ulster in 2009, for which my thesis was 'Reforming the Security Sector in the Context of Nepalese Transition and completed a Masters Degree in International Peacekeeping at National University of Ireland Galway in 2007. 